\title{
Pemanfaatan WhatsApp Group (WAG) sebagai Instrumen Penilaian Sikap Siswa MI Al-Islah Jepara di Masa Pandemi
}

\author{
Muhammad Fikri Abdun Nasir* \& Andi Prastowo \\ UIN Sunan Kalijaga Yogyakarta \\ *Email korespondensi: fikrimfan27@gmail.com
}

\begin{abstract}
Assessment is an important activity to determine success in the implementation of teaching and learning activities. Pandemic which requires teachers are expected to be creative and innovative in finding solutions such as utilizing technology, one of which is the WhatsApp application. This research uses a qualitative approach with the type of case study research where the location of this research was conducted at MI Al-Islah Jepara. The data was obtained through interviews with the homeroom teacher who became the main source, observations through the class WhatsApp Group (WAG). After the data is collected from the results of interviews and observations, then data reduction is carried out, namely the process of selecting data to classify more widely. After the data is reduced, then the data is presented, namely the data are arranged systematically to produce conclusions. As for this study, it can be concluded that the use of WhatsApp Group (WAG) is considered effective for assessing elementary school students in the affective domain during the Covid-19 pandemic.
\end{abstract}

Keyword: WhatsApp Group (WAG), Affective Assessment, Online Learning, Covid-19

Pandemic Period, Madrasah Ibtidaiyah

\section{Abstrak}

Penilaian merupakan kegiatan penting untuk menentukan keberhasilan dalam pelaksanaan kegiatan belajar mengajar. Pandemi Covid-19 mengharuskan guru mampu kreatif dan inovatif dalam mencari jalan keluar seperti memanfaatkan teknologi, salah satunya yakni aplikasi WhatsApp. Penelitian ini menggunakan pendekatan kualitatif dengan jenis penelitian studi kasus dimana lokasi penelitian ini dilakukan di MI Al-Islah Jepara. Data diperoleh melalui wawancara bersama wali kelas yang menjadi sumber utama, observasi melalui WhatsApp Group (WAG) kelas. Setelah data terkumpul dari hasil wawancara dan observasi kemudian dilakukan reduksi data, yakni proses pemilihan data guna menggolongkan lebih luas. Setelah data direduksi kemudian dilakukan penyajian data, yakni data disusun secara sistematis untuk menghasilkan kesimpulan. Adapun pada penelitian ini dapat ditarik kesimpulan bahwa penggunaan WhatsApp Group (WAG) dianggap efektif untuk menilai siswa sekolah dasar pada ranah sikap di masa pandemi Covid-19.

Kata kunci: WhatsApp Group (WAG), Penilaian Sikap, Pembelajaran Daring, Masa Pandemi Covid-19, Madrasah Ibtidaiyah 


\section{A. Pendahuluan}

Penilaian memiliki peran utama untuk mengukur keberhasilan dari informasi yang disampaikan oleh guru. Dalam permendikbud No. 23 Tahun 2016 tentang standar penilaian pendidikan tertulis bahwa penilaian merupakan proses pengumpulan informasi yang dilakukan secara terus-menerus untuk mengukur atau mengetahui seberapa jauh pemahaman siswa selama proses pembelajaran berlangsung. Sebagaimana hal ini sesuai dengan panduan penilaian sekolah dasar yang diterbitkan oleh direktorat pembinaan sekolah dasar, direktorat jenderal pendidikan dasar dan menengah (Kemendikbud, 2016) sebagai berikut:

Kurikulum, pembelajaran, dan penilaian merupakan komponen penting dalam kegiatan pembelajaran. Komponen tersebut saling terkait antara satu dengan yang lain. Kurikulum sebagai seperangkat rencana mencakup tujuan, isi, dan bahan pelajaran serta cara yang digunakan sebagai pedoman penyelenggaraan kegiatan pembelajaran untuk mencapai tujuan pembelajaran tertentu. Pembelajaran dilakukan sebagai upaya untuk mencapai kompetensi yang dirumuskan dalam kurikulum. Selain itu, penilaian erat kaitannya dengan informasi tentang peserta didik dan pembelajarannya.

Selain dijadikan sebagai bukti hasil pencapaian belajar siswa, penilaian juga dijadikan sebagai alat guru untuk menentukan apakah siswa sudah mengikuti dan sesuai dengan proses pembelajaran dengan benar atau belum (Kunandar, 2014). Penilaian pada kurikulum 2013 mencakup pada ranah pengetahuan, keterampilan, dan sikap secara utuh dan proporsional, sesuai dengan kompetensi inti yang telah ditentukan. Untuk memperbaiki kurikulum 2013 maka perlu dilakukan perbaikan pada aspek substansial maupun teknis implementasinya (Andi Prastowo, 2018)

Penilaian ranah pengetahuan (kognitif) dapat dilakukan dengan ujian tulis, lisan, dan daftar isian pertanyaan. Penilaian ranah keterampilan (psikomotor) dapat dilakukan dengan ujian praktik, analisis keterampilan dan analisis tugas, serta penilaian oleh siswa sendiri. Penilaian ranah sikap (afektif) dapat dilakukan dengan daftar isian sikap (pengamatan pribadi) dari diri sendiri dan daftar isian sikap yang disesuaikan dengan kompetensi inti (Mulyasa, 2014).

Sejak diumumkannya wabah Covid-19 di dunia sangat memberikan dampak yang signifikan terhadap semua sisi kehidupan manusia, tak lain pada dunia pendidikan. Karena penyebaran yang sangat masif sehingga pemerintah melarang masyarakat untuk berkerumun, pembatasan sosial (social distancing) dan menjaga jarak (physical distancing), memakai masker, dan selalu mencuci tangan. Kebijakan 
tersebut juga telah diimplementasikan dalam dunia pendidikan dengan dikeluarkannya surat edaran dari Kementerian Pendidikan dan Kebudayaan (Kemendikbud) No. 3 Tahun 2020 tentang pencegahan Covid-19 pada satuan pendidikan, dan surat edaran No. 4 Tahun 2020 tentang pelaksanaan kebijakan pendidikan dalam masa darurat penyebaran Corona Virus Desease (Covid-19).

Kebijakan pemerintah dalam surat edaran tersebut yakni terkait dengan sistem asesmen yang dilakukan, yakni dengan adanya pembatalan Ujian Nasional (UN), pelaksanaan pembelajaran dari rumah atau sistem pembelajaran jarak jauh (PJJ), ketentuan ujian sekolah untuk kelulusan, ketentuan kenaikan kelas, ketentuan pelaksanaan penerimaan peserta didik baru, penggunaan dana BOS (Kemendikbud, 2020).

Adanya kebijakan pemerintah untuk melaksanakan pembelajaran jarak jauh akan berdampak pada proses pembelajaran. Pembelajaran jarak jauh akan sulit untuk berinteraksi, guru tidak dapat memantau secara langsung proses pembelajaran dan terbatasnya kemampuan siswa dalam menerima materi yang disampaikan secara daring. (Firman dan Rahman, 2020) Hal ini dianggap kurang efektif karena apabila ada siswa yang kurang paham dengan materi yang disampaikan harus secara daring dan kemungkinan besar akan membuat siswa kurang puas dengan jawaban yang diberikan karena keterbatasan waktu, dan juga koneksi.

Pembelajaran daring merupakan kegiatan belajar mengajar yang dilaksanakan dengan berbantuan jejaring internet sebagai akses belajar. Pembelajaran daring adalah bentuk pembelajaran jarak jauh yang memanfaatkan teknologi telekomunikasi dan internet (Sadikin, 2020). Pelaksanaan pembelajaran daring mendukung penerapan pembelajaran di era 4.0 yang memanfaatkan teknologi yang memanfaatkan segala bentuk informasi digital dalam proses pembelajaran.

Pembelajaran daring sendiri merupakan pembelajaran yang menggunakan jaringan internet dengan aksesibilitas, konektivitas, fleksibilitas, dan kemampuan untuk memunculkan berbagai jenis interaksi pembelajaran. Sistem pembelajaran daring dapat mengoptimalkan antar siswa dan guru melalui forum diskusi yang 
terdapat pada media sosial, salah satunya yakni aplikasi WhatsApp (Ade R., dkk, 2020).

Penggunaan aplikasi WhatsApp sebagai media online sudah tidak asing lagi terdengar di kalangan masyarakat terutama dunia pendidikan. Pada dunia pendidikan, aplikasi WhatsApp bisa digunakan untuk membuat WhatsApp Group (WAG) yang terdiri dari guru, siswa dan wali siswa (bagi siswa kelas rendah). WhatsApp Group merupakan sebuah ruang kelas virtual yang memfasilitasi untuk berinteraksi antar anggota (Novita Puspa Dewi, 2020). Anderson menjelaskan terdapat tiga prinsip dalam penilaian pembelajaran, yakni bermakna, transparansi dan adil (Anderson, 2003). Dengan adanya pembelajaran daring tentunya membuat guru kesulitan dalam menilai siswa, terutama pada ranah sikap.

Fakta di lapangan, menunjukkan semua siswa memperoleh nilai maksimal ketika diberi soal. Hal tersebut menjadi pertanyaan bagi guru apakah siswa benarbenar memahami materi atau siswa mendapatkan bantuan dari orangtua ketika mengerjakan tugas. Sehingga yang terjadi adalah guru tidak dapat menilai ketercapaian pembelajaran secara obyektif sesuai dengan kemampuan siswa. Dari sisi sikap sendiri, biasanya penilaian terjadi secara alamiah ketika siswa berinteraksi, berkomunikasi, dan bersosialisasi dengan teman.

Peneliti sebelumnya telah menjelaskan tentang pelaksanaan penilaian sikap di SD Negeri 03 Pemalang. Penelitian tersebut menghasilkan bahwa dalam pelaksanaan penilaian sikap terdapat hambatan, yakni karena keterbatasan waktu sehingga guru lebih fokus pada pelaksanaan penilaian kognitif, disamping itu guru juga belum sepenuhnya mengenal karakter siswa.

Dari masalah tersebut peneliti telah memberi masukan kepada guru untuk lebih memahami pengertian dari penilaian sikap itu sendiri, sebaiknya penelitian sikap dapat dilakukan dengan penilaian diri, penilaian antar teman, dan guru diharapkan mampu mengelola waktu dengan baik (Rido Hoirinnisa K., 2019). Sedangkan peneliti menjelaskan kegiatan penilaian ranah sikap melalui WhatsApp Group di masa pandemi Covid-19, dengan tujuan mengetahui keefektifan penggunaan WhatsApp Group sebagai instrumen penilaian ranah sikap di masa pandemi Covid-19. 


\section{B. Metode Penelitian}

Penelitian ini menggunakan pendekatan kualitatif dengan jenis penelitian studi kasus (J.R. Raco, 2010). Penggunaan jenis penelitian ini bermaksud untuk mengetahui implementasi penggunaan WhatsApp Group (WAG) sebagai instrumen penilaian sikap siswa sekolah dasar di masa pandemi. Penelitian ini dilakukan di MI Al-Islah Jepara pada bulan maret. Data diperoleh melalui wawancara bersama wali kelas yang menjadi sumber utama dan observasi melalui WhatsApp Group (WAG) kelas. Setelah data terkumpul dari hasil wawancara dan observasi kemudian dilakukan reduksi data, yakni proses pemilihan data guna menggolongkan data lebih luas. Setelah data direduksi kemudian dilakukan penyajian data, yakni data disusun secara sistematis untuk menghasilkan kesimpulan (Sugiyono, 2011).

\section{Hasil Dan Pembahasan}

WhatsApp Group (WAG) sebagai Instrumen Penilaian Sikap Siswa Sekolah Dasar di Masa Pandemi

MI Al-Islah Jepara telah memanfaatkan WhatsApp Group (WAG) sebagai instrumen penilaian sikap siswa di masa pandemi. Sebelum melakukan penilaian, langkah yang dilakukan guru adalah sebagai berikut:

1) Guru membuat grup kemudian memasukkan nomor WhatsApp orang tua/wali siswa ke dalam WhatsApp Group (WAG);

2) Guru menyampaikan tata tertib diantaranya menjawab salam, absen, berdo'a dengan membuktikan siswa mengirim Voice Note (VN), mengirim tugas, mengirim bukti foto anak sedang belajar atau mengerjakan soal, bukti video anak sedang berdo'a dan hafalan. Guru mengirim materi berupa dokumen dan dijelaskan lewat Voice Note (VN) atau video;

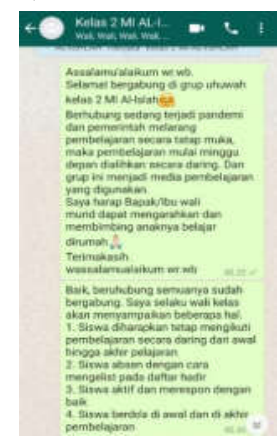

Gambar 1. Tata tertib dari guru 
3) Guru memulai kegiatan sesuai tata tertib

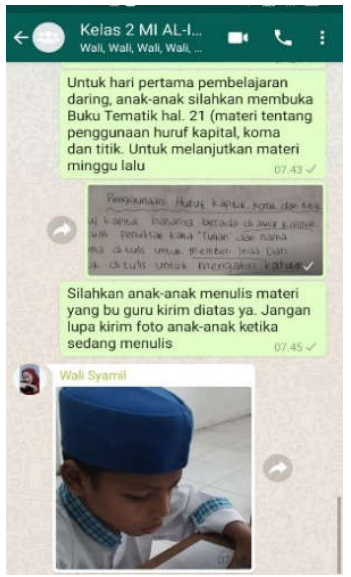

Gambar 2. Guru menyampaikan materi

Ketika materi sudah diterima siswa, diharapkan siswa dapat memahami materi tersebut, dan apabila ada yang belum paham guru memberi kesempatan kepada siswa untuk bertanya. Ketika siswa tidak ada yang bertanya lagi artinya siswa sudah paham materi yang telah disampaikan guru dan kegiatan selanjutnya yakni guru memberikan tugas kepada siswa sebagai penguat agar siswa lebih memahami materi yang sedang dipelajari. Nantinya tugas tersebut dikerjakan oleh siswa secara mandiri dibuktikan dengan mengirim gambar siswa sedang mengerjakan tugas, mengirim gambar hasil tugas dengan batas waktu yang telah ditentukan. Sebagaimana terlihat pada gambar di bawah.

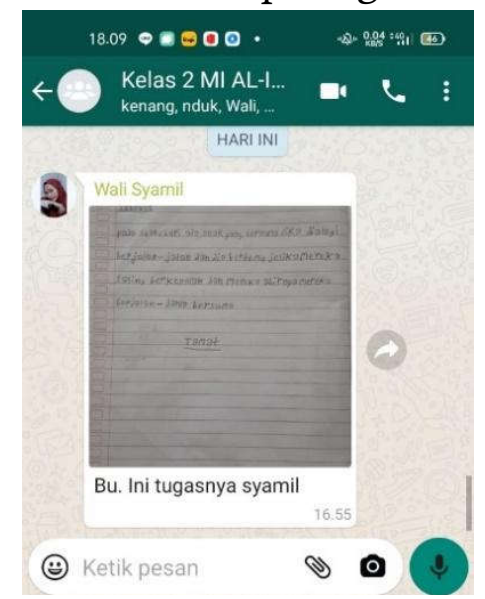

Gambar 3. Bukti siswa mengirim tugas

Hasil pengerjaan tugas tersebutlah yang digunakan untuk menilai kemampuan siswa. Dalam melakukan penilaian, guru harus melakukan beberapa tahapan, yakni: 1) mengidentifikasi penilaian ranah sikap, 2) penyusunan penilaian 
ranah sikap, 3) pelaksanaan penilaian sikap, dan terakhir 4) penilaian hasil akhir. Adapun hasil temuannya sebagai berikut:

a) Identifikasi penilaian ranah sikap

Penilaian ranah sikap sendiri mencakup pada penilaian sikap, minat, komunikasi. Adapun penilaian dapat dilakukan dengan mudah, salah satunya adalah dengan mengembangkan penilaian ranah sikap secara sistematik dan sistemik agar dapat mendisposisi peserta didik terkait aspek sikap, minat, konsep diri, nilai dan moral (Djemari Mardapi, 2017). Untuk memudahkan, guru bisa mengidentifikasi terlebih dahulu penilaian pada ranah sikap. Sebagaimana seperti yang dilakukan guru MI Al-Islah Jepara. Pengidentifikasian penilaian ranah sikap dilakukan dengan mengkaji kompetensi inti dan indikator yang telah ditetapkan lembaga.

b) Penyusunan penilaian ranah sikap

Penyusunan penilaian sikap guru menggunakan instrumen penilaian non tes yang dilakukan dengan teknik observasi. Kompetensi sikap sendiri terbagi menjadi dua, yakni sikap spiritual dan sikap sosial. Penilaian sikap spiritual dilakukan guru melalui observasi ketika sedang berlangsungnya kegiatan belajar mengajar, sikap spiritual mencakup siswa berdo'a sebelum dan sesudah pembelajaran. Sedangkan penilaian sikap sosial dilakukan guru melalui cara observasi ketika sedang berlangsungnya kegiatan belajar mengajar dalam hal kesantunan, kedisiplinan, keaktifan dalam menanggapi forum dan kepercayaan diri siswa selama dalam forum WhatsApp Group (WAG).

Berikut upaya yang dilakukan guru MI Al-Islah Jepara dengan menyiapkan lembar observasi ditentukan deskriptor sikap terlebih dahulu dengan kriteria dan skor pada tiap indikator. Sebagaimana terlihat pada tabel di bawah:

Tabel 1 deskriptor sikap spiritual

\begin{tabular}{|l|c|c|}
\hline \multicolumn{1}{|c|}{ Indikator } & Kriteria & Skor \\
\hline $\begin{array}{l}\text { Siswa berdo'a ketika di awal dan di akhir } \\
\text { kegiatan belajar mengajar }\end{array}$ & Sangat baik & 4 \\
\hline Siswa berdo'a di awal kegiatan belajar mengajar & Baik & 3 \\
\hline Siswa berdoa di akhir kegiatan belajar mengajar & Cukup & 2 \\
\hline $\begin{array}{l}\text { Siswa tidak berdo'a diawal maupun diakhir } \\
\text { kegiatan belajar mengajar }\end{array}$ & Kurang & 1 \\
\hline
\end{tabular}

Untuk deskriptor selanjutnya yaitu sikap sosial, sebagaimana terlihat pada tabel di bawah: 
Tabel 2 deskriptor sikap sosial (menanggapi/merespon, santun dan disiplin)

\begin{tabular}{|l|l|l|}
\hline \multicolumn{1}{|c|}{ Indikator } & Kriteria & Skor \\
\hline $\begin{array}{l}\text { Siswa selalu aktif dalam menanggapi/merespon } \\
\text { dan menggunakan bahasa yang santun }\end{array}$ & $\begin{array}{l}\text { Sangat } \\
\text { baik }\end{array}$ & 4 \\
\hline $\begin{array}{l}\text { Siswa sering aktif dalam menanggapi/merespon } \\
\text { dan menggunakan bahasa yang santun }\end{array}$ & Baik & 3 \\
\hline $\begin{array}{l}\text { Siswa kadang-kadang aktif dalam menanggapi/ } \\
\text { merespon dan menggunakan bahasa yang santun }\end{array}$ & Cukup & 2 \\
\hline $\begin{array}{l}\text { Siswa tidak pernah aktif dalam menanggapi/ } \\
\text { merespon dan menggunakan bahasa yang santun }\end{array}$ & Kurang & 1 \\
\hline
\end{tabular}

c) Pelaksanaan penilaian sikap

Guru mengamati siswa melalui keaktifan siswa di grup, guru menilai setiap siswa dengan lembar yang telah disiapkan. Guru membuat lembar penilaian disesuaikan pada kegiatan yang hendak dilakukan setiap harinya.

d) Penilaian hasil akhir

Guru membuat rekapitulasi hasil penilaian sikap siswa, untuk menentukan skor, guru membagi dua dari jumlah skor yang didapat. Sebagaimana terlihat pada tabel di bawah:

Tabel 4 rekapitulasi skor sikap siswa

\begin{tabular}{|l|c|c|c|c|l|}
\hline Nama siswa & S. S & S. SP & JML & Skor & Interpretasi \\
\hline Andi & 2 & 3 & 5 & 2,5 & Cukup \\
\hline Audi & 4 & 3 & 7 & 3,5 & Baik \\
\hline Cahaya & 3 & 3 & 6 & 3 & Baik \\
\hline Dini & 3 & 3 & 6 & 3 & Baik \\
\hline Fira & 4 & 4 & 8 & 4 & Sangat baik \\
\hline Rena & 4 & 4 & 8 & 4 & Sangat baik \\
\hline Syamil & 4 & 4 & 8 & 4 & Sangat baik \\
\hline Yossy & 2 & 3 & 5 & 2,5 & Cukup \\
\hline Mutia & 4 & 4 & 8 & 4 & Sangat baik \\
\hline Rara & 4 & 3 & 7 & 3,5 & Baik \\
\hline Marsya & 4 & 3 & 7 & 3,5 & Baik \\
\hline Danis & 4 & 2 & 6 & 3 & Baik \\
\hline Eko & 4 & 4 & 8 & 4 & Sangat baik \\
\hline Zakira & 3 & 3 & 6 & 3 & Baik \\
\hline Arista & 4 & 3 & 7 & 3,5 & Baik \\
\hline Kumala & 3 & 2 & 5 & 2,5 & Cukup \\
\hline
\end{tabular}

Dilihat dari tabel rekapitulasi skor sikap siswa terlihat hasil skor rata-rata tinggi, itu artinya penilaian pada ranah sikap berbasis WhatsApp Group (WAG) terlaksana dengan baik dan terlihat efektif.

Meskipun demikian, guru mengalami hambatan selama kegiatan pembelajaran yang dilakukan secara daring, sebagaimana dijelaskan guru kelas II berikut: 
Penilaian sikap yang seharusnya dilakukan secara tatap muka karena adanya pengawasan dari guru langsung kini tergantikan oleh canggihnya teknologi. Disini siswa mengikuti instruksi entah atas kemauan sendiri atau paksaan orang tua, yang penting ada bukti siswa melakukan perintah guru. Selain itu, dalam komunikasi yang seharusnya dinilai ketika sedang berinteraksi secara langsung. Dan lagi yang menjadi masalah terbesar adalah waktu. Biasanya dilakukan secara otodidak, sekarang melalui WhatsApp Group harus menunggu sampai seharian penuh. Kadang koneksi internet juga tidak stabil membuat banyak memakan waktu (Cholifah: 2021).

Berangkat dari masalah di atas, menurut Syah faktor psikologis dari luar siswa berpengaruh pada kegiatan belajar siswa (Muhibbin Syah, 2013). Oleh karena itu guna menyiasati kendala tersebut, guru dapat memanfaatkan portal kemendikbud melalui siaran televisi. Hal ini juga menjadi solusi ketika ada siswa yang tidak memiliki handphone.

\section{Pembahasan}

Pesatnya penularan virus akibat pandemi Covid-19 membawa dampak yang luar biasa dalam dunia pendidikan. Hal ini pemerintah memutuskan untuk melaksanakan kegiatan belajar mengajar dari rumah atau dengan cara daring. Pembelajaran daring adalah bentuk pembelajaran jarak jauh yang memanfaatkan teknologi. Dengan adanya penerapan pembelajaran daring, peserta didik dalam pembelajaran memerlukan adanya peran guru yang akan memberi perubahan. Astini menjelaskan dengan pembelajaran jarak jauh ini merupakan inovasi pendidikan untuk menjawab tantangan yang sedang terjadi untuk menjadikan sumber belajar yang lebih variatif (Astini, 2020).

Kegiatan pembelajaran daring tidak hanya mengubah cara pembelajaran, tentunya juga mengubah teknik penilaian yang dilakukan guru. Kegiatan penilaian merupakan hal yang penting dimana penilaian ini dilakukan untuk mendapat informasi hasil belajar siswa dan merupakan satu kesatuan dalam kegiatan belajar mengajar (Asrul, dkk, 2015). Penilaian harus dilakukan secara komprehensif meliputi aspek sikap, pengetahuan, dan keterampilan.

Pelaksanaan pembelajaran daring menimbulkan masalah baru dalam hal penilaian siswa. Menurut Anderson terdapat tiga prinsip dalam penilaian pembelajaran, yaitu bermakna, transparansi dan adil. Ketiga prinsip tersebut akan sulit dilakukan secara maksimal oleh guru (Anderson, 2003). Adil dalam penilaian mempunyai makna bahwa setiap siswa mempunyai kesempatan yang sama dalam 
sistem penilaian, bukan berarti setiap siswa mendapatkan nilai yang sama, akan tetapi mendapatkan nilai yang sesuai dengan kemampuan belajar masing-masing.

Fakta di lapangan, menunjukkan semua siswa memperoleh nilai maksimal ketika diberi soal. Hal tersebut menjadi pertanyaan bagi guru apakah siswa benarbenar memahami materi atau siswa mendapatkan bantuan dari orangtua ketika mengerjakan tugas. Sehingga yang terjadi adalah guru tidak dapat menilai ketercapaian pembelajaran secara obyektif sesuai dengan kemampuan siswa (Maria A., 2021)

Penilaian ranah sikap yang dilakukan guru merupakan salah satu unsur terpenting yang tidak dapat diabaikan, penilaian ranah sikap meliputi sikap, minat, dan persepsi (Edward K., 1997). Sikap merupakan bagian dari kepribadian seseorang. Sikap menurut Arikunto merupakan bagian dari tingkah laku sebagai gejala atau gambaran kepribadian yang memancar keluar (Arikunto, 2012). Adanya pembelajaran daring, membuat guru kesulitan dalam menilai pada ranah sikap siswa karena tidak tatap muka langsung.

Seperti halnya yang dikemukakan oleh Hall menurut data yang diperoleh dalam penelitiannya "Status Sikap Siswa" pendidik berada pada posisi yang jauh lebih baik dalam upaya memberikan pengalaman pendidikan yang jelas, relevan, dan menarik bagi siswa (Hall, R. A., 2011). Dengan kata lain, penilaian sikap dapat memberikan informasi yang sangat dibutuhkan. Tanpa itu, pengalaman pendidikan akan menjadi kurang lengkap.

Adanya pandemi Covid-19 banyak sekolah berlomba-lomba menggunakan media yang mempermudah kegiatan belajar mengajar, salah satunya yakni penggunaan media WhatsApp Group. WhatsApp Group dapat digunakan guru untuk membagi materi pembelajaran kepada siswa, dan siswa dapat mengikuti pembelajaran walau tidak berada dalam pengawasan guru secara langsung. Sekolah memberikan ruang kepada guru untuk dapat mengembangkan pola pembelajaran di kelasnya, sebab ketidaksiapan dan mendadaknya waktu untuk pembelajaran daring.

Guru dikatakan profesional apabila mampu menginternalisasi nilai, pengetahuan, sikap, dan keterampilan siswa, dan juga mampu menjadi motivator untuk mengimplementasikan nilai-nilai yang telah diajarkan pada peserta didik 
(Andi Prastowo, 2013). Guru diharapkan mampu mengonsep pembelajaran yang menarik sehingga siswa dapat menerima pembelajaran dengan mudah dan mencapai hasil sesuai tujuan pembelajaran yang telah ditentukan (Laesari I. dan Hilmi Adisenjdjaja Y, 2018).

Kajian terdahulu dalam penggunaan WhatsApp Group sebagai media pembelajaran mengungkap bahwa aplikasi WhatsApp memiliki dampak positif pada keberhasilan pembelajaran daring, dan cukup baik digunakan dalam pembelajaran daring. Meskipun demikian, dalam kenyataannya penggunaan aplikasi WhatsApp tidak sepenuhnya mempengaruhi hasil atau nilai belajar (Putikayasa, 2019). Hal ini dikarenakan penggunaan aplikasi WhatsApp yang secara mendadak, terutama bagi siswa kelas rendah. Peran orang tua disini sangat diperlukan karena siswa Madrasah Ibtidaiyyah yang kategorinya masih kelas rendah perlu bimbingan dan arahan untuk pembelajaran daring berbasis WhatsApp.

Pada proses identifikasi penilaian ranah sikap, guru melaksanakan identifikasi penilaian ranah sikap dengan mengacu pada kompetensi inti dan indikator yang telah ditetapkan lembaga. (Heri Setiawan, Turmudi, 2019) Peneliti berharap dalam penilaian harus dilakukan dengan cara yang teliti agar penilaian pada ranah sikap dapat berjalan sesuai tujuan yang ditetapkan.

Proses penetapan instrumen, rubrik dan kriteria penilaian sikap harus sesuai dengan indikator dan kompetensi inti, disini guru harus rinci dan teliti agar guru dapat menunjukkan kemampuan siswa pada ranah sikap. Pelaksanaan penilaian dengan menyiapkan instrumen melalui WhatsApp Group dengan waktu yang ditentukan terlaksana dengan baik. (Heri Setiawan, Turmudi, 2019) Peneliti melihat penilaian ini dilakukan dengan objektif tanpa rekayasa dan manipulasi skor siswa. Dalam mengolah skor siswa dilakukan guru guna mengetahui seberapa jauh siswa memahami dan mampu mengaplikasikan dalam kehidupan sehari-hari.

Kemampuan siswa dalam ranah sikap terukur dengan jelas dan sistematis. Hal ini dapat dilihat dari wujud nyata keseharian siswa dalam proses pembelajaran seperti: perhatian terhadap mata pelajaran, kedisiplinan, motivasi belajar, rasa ingin tahu tinggi, rasa hormat terhadap guru dan semuanya (Anas Sujono, 2006). Terdapat dua hal yang berhubungan dengan penilaian sikap yang pertama, kompetensi sikap yang ingin dicapai dalam pembelajaran meliputi: banyaknya 
pemberian respon apresiasi, penilaian dan internalisasi. Kedua, sikap dan minat peserta didik terhadap mata pelajaran dalam kegiatan belajar mengajar. Dalam proses pembelajaran terdapat empat tipe karakteristik sikap yang penting yaitu sikap, minat, konsep diri dan nilai (Sukanti, 2011). Hal ini sesuai dengan penilaian ranah sikap yang dilakukan guru pada siswa kelas II MI Al-Islah Jepara.

Penelitian yang dilakukan menunjukkan hasil melalui wawancara dan observasi mengenai pelaksanaan penilaian pada ranah sikap dengan media WhatsApp Group pada siswa kelas II MI Al-Islah Jepara berjalan dengan baik. Guru dapat menggunakan aplikasi sesuai dengan apa yang diharapkan madrasah dan siswa pun dapat mengikuti pembelajaran dengan maksimal. WhatsApp Group yang digunakan sebagai media pembelajaran di MI Al-Islah sangat membantu baik kepada guru maupun siswa dalam pengoprasiannya. Evaluasi Pun dapat dilakukan oleh guru melalui WhatsApp Group, siswa dapat dinilai dari ranah kognitif, sikap, maupun psikomotoriknya malaupun tidak secara tatap muka antara guru dan siswa.

\section{Kesimpulan}

Pada penelitian ini MI Al-Islah Jepara telah memanfaatkan aplikasi WhatsApp Group (WAG) sebagai media untuk pembelajaran daring. Guru menyiapkan segala kebutuhan, terutama pada hal penilaian. Karena pada penilaian sikap siswa yang lebih sulit ketika pembelajaran daring, terlebih dahulu guru mengidentifikasi penilaian pada ranah sikap, guru mengkaji kompetensi inti dan indikator yang telah ditetapkan. Selanjutnya melakukan penyusunan rubrik penilaian, dan yang terakhir yakni pengolahan nilai/skor. Dari hasil penelitian menghasilkan bahwa penggunaan WhatsApp Group (WAG) yang dilakukan di MI Al-Islah Jepara dianggap berjalan dengan baik untuk menilai pada ranah sikap di masa pandemi Covid-19. Meskipun berbeda dengan penilaian secara tatap muka, penilaian ini juga dapat dikatakan berhasil dengan standar yang berbeda tentunya. Guru Pun menyadari untuk tidak menyamakan hasil belajar siswa ketika tatap muka dengan daring. Namun demikian, amanat pendidikan tetap harus dilaksanakan dan menjadi tanggung jawab bersama. 
Berdasarkan kesimpulan di atas, maka implikasi dari penelitian ini merekomendasikan 1) pentingnya upaya guru dalam menyiapkan berbagai strategi pelaksanaan penilaian, terutama penilaian pada ranah sikap. Guru dituntut kreatif dan inovatif, karena guru merupakan tombak dalam tolak ukur keberhasilan siswa. 2) orang tua diharapkan turut memotivasi anaknya dan terus mendampingi proses belajar mengajar di masa pandemi Covid-19. 3) siswa diharapkan dapat mengetahui hasil capaian selama pembelajaran di masa Covid-19, dengan demikian siswa mengetahui sejauh mana keberhasilan yang telah dicapai selama mengikuti kegiatan belajar mengajar di masa pandemi Covid-19.

\section{Daftar Pustaka}

Ana Maria, Theodosia Ndole. (2021). Efektivitas Penilaian Pembelajaran Matematika Selama Masa Pandemi Covid-19 SDK Ndona 2 Kecamatan Ndona Kabupaten Ende. Jurnal Pendidikan Matematika Universitas Flores. Vol. 4 No. 1.

Anderson, L. W. (2003). Classroom assessment: Enhancing the quality of teacher decision making. New Jersey: Lawrence Erl-baum Associates Inc.

Arikunto, S. (2012). Dasar-dasar Evaluasi Pendidikan Edisi 2. Jakarta: Bumi Aksara.

Asrul, Ananda, R., Rosnita. (2015). Evaluasi Pembelajaran. Citapustaka Media.

Astini, S. (2020). Pemanfaatan Teknologi Informasi dlam Pembelajaran Tingkat Sekolah Dasar pada Masa Pandemi Covud-19. Jurnal Lampuhyang. Vol. 11 No. 2

Cholifah Siti. (2021). Wawancara.

Firman dan Rahman. (2020). Pembelajaran Online di Tengah Pandemi Covid-19. Indonesian Journal of Educational Science (IJES). Vol. 2 No. 2.

Hall, R. A. (2011). Affective Assesment: The Missing Piece of The Educational Reform Puzzle. Delta Kappa Gamma Bulletin: International Journal for Proffesional Educatos. Vol. 77 No. 2.

Harnani Sri. (2020). Efaktivitas Pembelajaran Daring di Masa Pandemi Covid-19. https://bdkjakarta.kemenag.go.id/berita/efektivitas-pembelajaran-daring-dimasa-pandemi-Covid-19. Diakses pada tanggal 23 Maret 2021.

Imania, kuntum An Nisa. (2019). Rancangan Pengembangan Instrumen Penilaian Berbasis Daring. Jurnal IPTEK. Vol 5. https://journal.institutpendidikan.ac.id/index.php/petik/article/view/445. Diakses pada tanggal 25 Maret 2021. 
Kementerian Pendidikan dan Kebudayaan. (2020). Mendikbud terbitkan SE tentang Pelaksanaan Pendidikan dalam Masa Darurat Covid-19. https://www.kemdikbud.go.id/main/blog/2020/03/mendikbud-terbitkan-setentang-pelaksanaan-pendidikan-dalam-masa-darurat-Covid-19. Diakses pada tanggal 23 Maret 2021.

Kifer I, Edwar. (1997). An Approach to The Contruction of Affective Evaluation Instrumens. Journal of Youth and Adolescene. Vol. 6 No. 3.

Kunandar. (2014). Penilaian Autentik (Penilaian Hasil Belajar Peserta Didik Berdasarkan Kurikulum 2013): Suatu Pendekatan Praktis Disertai Dengan Contoh. Ed. Rev. Jakarta: Rajawali Pers.

Kurniati, Rido Hoirinnisa. (2019). Pelaksanaan Penilaian Sikap di SD Negeri 03 Cibelok Kecamatan Taman Kabupaten Pemalang. Skripsi: Universitas Negeri Semarang.

Leasari I. dan Anggraeni S. (2017). Mengeksplorasi Kemampuan Berpikir Kritis dan Rasa Ingin Tahu Siswa Melalui Kegiatan Laboratorium Inquiry Sederhana.

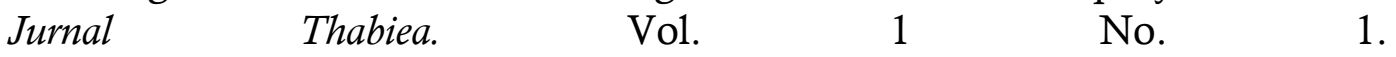
https://journal.stainkudus.ac.id/index.php/Thabiea.

Mardhapi Djemari. (2017). Pengukuran, Penialian, dan Evaluasi Pendidikan. Yogyakarta: Nuha Medika.

Mulyasa. (2014). Pengembangan dan Implementasi Kurikulum 2013. Bandung: PT Remaja Rosdakarya.

Permendikbud. (2016). Peraturan Mentri Pendidikan dan Kebudayaan Nomor 24 Tahun 2016 Tentang Kompetensi Inti dan Kompetensi Dasar Pelajaran Pada Kurikulum 2013 Pada Pendidikan Dasar dan Pendidikan Menengah.

Pertiwi, W. (2020). WhatsApp Tembus 2 Miliar Pengguna. https://amp.kompas.com/tekno/read/2020/02/13/18190017/whatsapptembus-2-miliar-pengguna. Diakses pada tanggal 22 Maret 2021.

Prastowo Andi. (2018). Transformasi Kurikulum Pendidikan Dasar dan Menengah di Indonesia. Jurnal Ilmiah PGMI. Vol 4 No. 2.

Prastowo Andi. (2013). Kapasitas Guru Profesional di Pendidikan Dasar Islam. Literasi (Jurnal Ilmu Pendidikan). Vol. 4 No. 2.

Puspa Nofita Dewi. (2020). Penerapam Pembelajaran IPA Daring Berbasis WhatsApp Group untuk Sswa Madrasah Ibtidaiyyah di Tengah Pandemi Covid-19. Jurnal Penelitian. Vol. 14 No. 2.

Pustikayasa I.M. (2019). Group WhatsApp Sebagai Media Pembelajaran (WhatsApp Group as Learning Media), Jurnal Ilmiah Pendidikan, Agama dan Kebudayaan Hindu. Vol. 10 No.

Rahma Ade Gusti, Dkk. (2020). Penilaian Sikap Pembelajaran Daring IPA Terpadu dengan Menggunakan Media WhatsApp. Journal for Physics Education and Applied Physich. Vol. 2 No. 2

Sadikin, A. \& Hamidah, A. (2020). Pembelajaran Daring di Tengan Wabah Covid-19. Jurnal Ilmiah Pendidikan Biologi. Vol. 6 No. 2. 
Setiawan Heri, Turmudi. (2019). Pengembangan Instrumen Asesmen Kompetensi Ranah Sikap di Sekolah Dasar. Musamus Journal of Primary Education. Vol.2 No.1.

Sugiyono. (2013). Metode Penelitian Pendidikan Pendekatan Kuantitatif, Kualitatif, dan $R \& D$. Bandung: Alfabeta.

Sujono Anas. (2006). Pengantar Evaluasi Pendidikan. Jakarta: PT. Raya Grafindo Persada.

Sukanti. (2011). penilaian sikap dalam pembelajaran akuntansi. Jurnal pendidikan akuntansi indonesia. Vol.9 No.1.

Syah Muhibbin. (2013). Psiklogi Pendidikan: dengan Pendekatan Baru. Bandung: Remaja Rosdakarya.

Wahyu Aji Fatma Dewi. (2020). Dampak Covid-19 terhadap Implementasi Pembelajaran Daring di Sekolah Dasar. Edukatif: Jurnal Ilmu Pendidikan. Vol. 2. No. 1. https://edukatif.org/index.php/edukatif/article/view/89/pdf. Diakses pada tanggal 24 Maret 2021. 
Pemanfaatan WhatsApp Group (WAG) sebagai Instrumen Penilaian Sikap ... 